\title{
THINKING BEYOND THE SQUARE: INNOVATION THEORY AND TECHNOLOGY TRANSFER AS THEY APPLY TO THE BEIJING WATER CUBE
}

\author{
KIRSTEN ORR \\ Faculty of Design, Architecture and Building \\ University of Technology, Sydney \\ PO Box 123, Broadway, NSW 2007, Australia \\ Kirsten.orr@uts.edu.au
}

\begin{abstract}
The Water Cube National Swimming Centre designed for the 2008 Beijing Olympics has been hailed as a highly innovative post-millennial sports facility. Conceptually, its architecture is a cube, carved from a random, organic and homogeneous cluster of foam bubbles. Structurally, it is a mathematically rigorous steel space frame, primarily of pentagonal and hexagonal cells. Materially, it is clad inside and out with ethylene-tetra-fluoro-ethylene (ETFE) cushions whose translucent skin captures and translates water's natural transient and organic properties to a new context that is ancient, landlocked and manmade. The winning design consortium comprised the Australian architectural firm PTW, Arup (Australia) and China State Construction Engineering Corporation - Shenzhen Design Institute. This paper examines the success of the consortium in the light of innovation theory: it considers the drivers behind the collaborative effort, the structure and characteristics of the design team, and the role of technology transfer in the innovation process. Research shows that innovation in the construction industry is linked to a demand for radically new types of buildings and structures. The Beijing Games have provided such a demand as its purpose-built facilities strive to couple challenging programmatic requirements with cultural aspirations.

The Water Cube is a unique coalescence of Chinese cultural traditions, favouring axial arrangements and rectilinearity in the built environment, with current Western trends towards asymmetric organic forms and structures derived from nature. It has been achieved by the transfer of digital technology to architecture and engineering and by the application of an emergent building material, ETFE. The dynamics of the teamwork approach to design provided rich multi-cultural perspectives and diverse technological know-how that allowed for technology transfer and innovation to take place.
\end{abstract}

Keywords: Architecture, innovation, Water Cube, Beijing, Olympic. 


\section{Introduction}

The Water Cube National Swimming Centre designed for the 2008 Beijing Olympics by the Australian architectural firm, PTW, in partnership with local architects China State Construction Engineering Corporation - Shenzhen Design Institute (CSCEC-SDI) and with engineering input from the Sydney office of Arup (Australia), has been hailed as a highly innovative post-millennial sports facility. Conceptually, its architecture is a cube, carved from a random, organic and homogeneous cluster of foam bubbles. Structurally, it is a mathematically rigorous steel space frame, primarily of pentagonal and hexagonal cells. Materially, it is clad inside and out with ethylene-tetra-fluoro-ethylene (ETFE) cushions whose translucent skin captures and translates water's natural transient and organic properties to a new context that is ancient, landlocked and manmade.

The (limited) literature on the Water Cube is fixated on how the architecture/engineering has made possible the realisation of a lightweight construction derived from the structure of water in the state of aggregation of foam (Rabagliati). This paper steps beyond the 'how' to contribute a new understanding of innovation theory and technology transfer as they apply to the Water Cube. The methodology is based on an analysis of the recognised drivers for innovation and the components of technology transfer, and is informed by a series of interviews conducted by the author with the project architects at PTW.

\section{Innovation Theory}

Innovation is defined by the Australian Bureau of Statistics (ABS) in its survey, Innovation in Australian Business 2005, as "the process of developing, introducing and implementing a new or significantly improved good or service or a new or significantly improved process" (46). The $A B S$ research reveals that the construction industry performs poorly in innovative activities compared to other Australian industries. This accords with the scant attention paid to the workings of the construction industry in innovation literature, a review of which was completed by Christine Miller, Robert Carr and Wilfred Cheung in 2001. Literature on innovation in architecture is even scarcer and mostly comprises case studies examined individually and in isolation from a theoretical framework (Brookes and Poole).

Much innovation theory derives from studies of assembled products and explores the interrelationship between product and process innovation. William Abernathy's research on the auto industry is a well-known example. A highly valued product like a car is the result of a continuous, "fine scale" development process involving multiple inputs that are combined and transformed through a complex production process. James Utterback finds that a similar interrelationship between product and process innovation also applies to non-assembled products such as glass and steel, but that the development process differs because it is periodic and discontinuous. For example, the development of float glass technology by Pilkington was a large technological leap (104-116). This kind of discontinuous innovation is described by Philip Anderson and Michael Tushman as coming from a technology that "inaugurates an era of ferment in which competition among variations of the original breakthrough culminates in the selection of a single dominant configuration of [a] new technology" (606). Innovation is a process and technology transfer is a means by which innovation is achieved (Cooke and Mayes 11).

Architectural innovation involves both the fine-scale development of existing products and large technological leaps that transform the discipline. Mike Cook, a structural engineer with Buro Happold, describes fine-scale innovation as originating from people who are masters of their field moving "ideas forward in small steps using new tools or applying established techniques in new areas," while innovation on a grand scale comes from people "working and thinking "at the edge' of their discipline" (in Brookes and Poole 82).

The most important aspect of a technical innovation is the visual or experiential idea that it helps to bring nearer to fruition... without the desire to make a better expression of a particular idea, technical innovation lacks a cultural and social purpose" (Brookes and Poole 111).

\section{Drivers of Innovation}

The ABS survey, which is based upon an international framework provided by the Oslo Manual, Guidelines for Collecting and Interpreting Innovation Data, identifies three major categories of drivers of innovation: profit, market and legal-related. Respondents could also nominate "other 
drivers" and the Construction Industry did this at a higher rate than most other industry groups, possibly because of its ad hoc structure and the prevalent conception of building projects as "one-offs." It has been demonstrated that the drivers of innovation within the construction industry are historically strongest when there is a demand for radically new types of buildings and structures (Gann 10). The Modern Olympic Games provide such a demand.

The architectural setting of each Olympiad is important as host cities and nations strive to present a distinctive image to the world, to establish a leading status in the global order, and to project official ideologies to the local population. Olympic projects are characteristically largescale undertakings with large budgets. The architecture is frequently progressive and technologically advanced, but may also incorporate unique elements derived from the local cultural heritage. For the international audience, recognisable features of the Olympic architecture screened by the media become symbols of the place and the time. For the local population, the physical transformation of their city through new buildings and infrastructure affects their relationship with it, often engendering city pride and fostering national identity (Orr, "Force for Federation").

The Modern Olympic Games are clearly more than just a flurry of national cultural assertiveness and international cultural diplomacy: they provide periodic occasions for symbolic architectural expression that contribute to the continuum of architectural development. The founder of the Games, Pierre de Coubertin, thought that a suitable physical setting was essential to give aesthetic and philosophical meaning to the athletic contests. He was behind the competition in 1910 for the design of "A Modern Olympia" seeking an innovative and inspirational architecture, worthy of its function and appropriate to the host city.

It is for the architects now to fulfill the great dream, to let soar from their brains a resplendent Olympia, at once original in its modernism and imposing in its traditionalism, but above all perfectly suited to its function (qtd. in Wimmer 216).

In conceptualising the architectural setting, de Coubertin was inspired by the ruins of Olympia and by the architecture of the nineteenth-century international exhibitions. The Great Exhibition of 1851 relied for its success on the spectacular Crystal Palace to bring people together in a spirit of "peace, progress, and prosperity" (Auerbach 230). Here, the horticultural glasshouse was transformed into a magnificent and vast, yet economical, structure capable of being constructed in an amazingly short space of time: craft-based traditions were replaced by the prefabrication capabilities of modern industry. The Crystal Palace exemplifies the manner in which buildings for the international exhibitions, and later, the Olympic Games, relied upon a new ceremonial public architecture that demanded innovation in construction techniques and technologies.

Through the transfer of new materials and technologies, the Munich Olympic Games (1972) managed to create a light-hearted spirit in which architecture and nature formed a harmonious recreational landscape of flowing curves and spaces. It was an opportunity to show the world that the character of Germany had changed since the Fascist period. The jury withheld comment on the feasibility of the tent roof proposed in Behnisch \& Partners' winning scheme because it was an unproven proposition that departed from architectural convention. Yet the great roof was the essence of the proposal: "an integrating element, evocative of the surrounding terrain, yet lifting off from it, like one of those manned kites in the sketchbooks of Leonardo" (Mahler 26). Frei Otto used physical models to find the natural equilibrium of physical forces and to define the desired complex forms - soap film models were used to define the minimal-surface tension structures and sprung-chain models to define cable-nets of equal stress. Research in experimental physics was transferred to architectural applications.

The Olympic imperative for innovation is enhanced when a host nation's organising elites place a high value on the staging of the Games for nation building and reform. This was as much the case for Seoul (1988) as it had been for Munich. The South Korean government, "and the USAeducated military-bureaucratic-corporate 'establishment' elite at is heart, used the staging of the Olympic Games ... instrumentally to achieve a number of nationalistic, political, economic and cultural goals," including recognition as a technologically modern society (Roche 148). A strategic element in this image-making was the architecture of the Olympic facilities, whose cable domes were the first tensegrity-type domes to be realised in the world. In addition, the state-of-the-art telecommunications infrastructure developed for the Games enabled South Korea to become world leaders in the field.

The next Olympic Games will be staged in Beijing (2008) - the political, educational, and cultural center of the People's Republic of China. According to the sports historian, Professor 
Fan Hong, the Olympics will be the "biggest event in China since the Communist Revolution in 1949," and will represent the fruition of a communist ideology that utilises sporting success to engender Chinese patriotism and unity (qtd. in Toy 17). China is rapidly emerging as a superpower, likely to overtake the United States as the largest world economy if current growth rates continue. Hosting the Olympics will be a milestone in the reinvention of a Communist regime in the context of a predominantly capitalist global community. The \$US40 billion program to rebuild Beijing extends beyond simply preparing the city for the Olympics, to building a capital commensurate with China's ambitions.

China's long history of innovation is examined by Paul Herbig in the light of the inhibitory impact of Communism (227-229). Whereas innovation tends to flourish in competitively driven, capitalist societies that place a high value on freedom of the individual, it is relatively suppressed in collectivist societies where an authoritative political system requires submission of individuals to a dogmatic social philosophy. Through a series of cross-cultural case studies, Herbig develops an innovation matrix to chart the ways in which the cultural attributes or sociocultural attitudes of a society in conjunction with the existing infrastructure of that society influence its ability to generate technological innovations. Under Communism, China's infrastructure has been inadequate to support innovation, a difficulty which it is rapidly overcoming. Professor Shujie Yao, at The University of Nottingham, describes China's policy to be one of pursuing "a gradual, pragmatic approach to reform, taking maximum advantage of foreign investment to build its exports and selectively importing science and technology to stimulate its own domestic development." The Beijng organisers are seeking to display China's progress through a successful Games set against the backdrop of iconic architecture. A series of architectural competitions were staged to capture the best ideas from the West and transfer them to China. To assist with the transfer of knowledge, a condition of the competitions was the inclusion of Chinese partners in the consortia (Bilmon, "Interview").

\section{Water Cube National Swimming Centre}

Entries for the Beijing National Swimming Centre came from a large number of high-profile international architectural companies such as HOK Sport (UK), Dominique Perrault (France), Rafael Vinoly Architects (USA), Foster \& Partners (UK), Cox Group (Australia) and Takamatsu Architects (Japan). They were attracted by the enormous commercial opportunities for business profit and global market share. The ABS finds that "profit related drivers were the most frequently cited reasons driving innovation, reported by $94.2 \%$ of businesses. Market related drivers were reported by $88.9 \%$ of innovating businesses" ("Notes"). Jon Sundbo argues that in the current economic cycle, the major driving force for innovation is interpretation of the market and profiting from the sale of products on it. Unlike the period from the 1930s to the 1960s, which was driven by technological development, the market now comes first and technological development, which is running quite efficiently, will follow.

PTW is an Australian company actively engaged in the Asian market, with six overseas offices. It completed its first project in China in 1992 (Shenzhen Development Bank) and in 2000-2001 established a wholly foreign owned enterprise in Shanghai-Pudong, with branches in ShanghaiPuxi and Beijing. Fifty percent of the company's revenue in 2006 was derived from overseas operations. Like any architectural business interested in securing top-end projects and exploring off-shore markets, PTW is attracted by the prestige and exposure of Olympic projects as a means of increasing market share. PTW already has a track record of innovative pool design and expertise in Olympic overlay planning and seating bowl arrangements from previous work for the Sydney (2000) and Athens (2004) Olympics. Nevertheless, the company almost withdrew from the Expression of Interest process because of the enormous risks involved: the financial and resource-intensive demands of preparing a submission were difficult to justify given the slim chance of winning an international competition and the difficult prospect of working in Beijing on the first Olympic facility to be completed there. The hesitation of the PTW Board of Directors is supported by the ABS data, which shows the most common barrier to innovation to be high direct costs that negatively impact profit. However, the company possesses most of the characteristics identified by the ABS as indicative of innovative ability: it is a large business; it has favourable business locations across Australia and Asia; it has a diverse staff upon whose ideas, knowledge, and skills it can draw; and it is experienced in multi-disciplinary collaborative ventures.

The winning scheme designed by PTW is an orthogonal form based on the square, a traditional organizational device in Chinese city planning and architecture, and located on the significant north-south axis that runs through Tiananmen Square. It is one half of the 'yin and yang' elements of the Beijing Games. The round 'masculine' stadium (by Herzog \& de Meuron), 
glowing red, is fire, or the 'yang', and the square 'feminine' Water Cube with its baby-blue hue, is water, or the 'yin'.

The restraint of the square shape posed an architectural challenge. Its monumental unbroken box form, 177 square metres by 31 metres high, demanded an innovative treatment of façade, fabric and structure to give it unique character. Starting with the idea of water and its qualities of translucency, the team considered the architectural applications of ETFE. This product was originally developed for the aeronautics industry and its transfer to the construction industry is recent. A wave of global interest in the architectural applications of ETFE was generated when Nicholas Grimshaw used it for the huge Eden Project conservatories (2000). The appealing property of ETFE is that the resin can be spun into a thin, light, elastic, durable, transparent film that has self-cleaning and structural properties (Woyke). PTW is using the material for the first time because it meets a number of aesthetic, environmental and engineering requirements. The risks on a project of this scale are high but overcome in this case by the Chinese commitment to innovate and by a strategic reshuffling of personnel and a commercial arrangement between the ETFE manufacturer, Vector Foiltec, and CSCEC.

The use of ETFE for the Water Cube is an example of the transfer of an available technology to a new application to achieve innovative aesthetic, experiential and functional solutions. The bubble concept was not simply applied as a pattern of circles of different diameters to the surface of a conventional structure, but became the basis for a radically new approach integrating aesthetic, environmental and structural agendas into an "insulated greenhouse" concept.

\section{Teamwork: cross-disciplinary and cross-cultural collaboration}

Innovation theory emphasises the essential role of teams and examines structures for effectiveness and efficiency and the spectrum of expertise and personal qualities that members should combine (Von Stamm). Mike Davies, from Richard Rogers Partnership, claims that his firm's most important design weapon is its strong and robust team of highly creative and completely differently skilled individuals who work constructively together. He says, "You have to have concept-makers, movers, developers, doers, providers, polishers and finishers" (in Brookes and Poole 22). The facilitation of teamwork at PTW appears to be extremely important to the company's success. PTW's operations are informed by a concept of integrated practice and a collaborative and cross-disciplinary team approach to design projects. It has developed a corporate structure diagram resembling a flower in which the central stamens, representing the Directors, are surrounded by concentric circles of Executive and Support staff. The individual design teams are the petals of the flower. New petals can be added as multi-disciplinary teams are formed (Bilmon, "Export").

The PTW architectural staff working on the Water Cube combined the talents of experienced senior design architects such as Associate Director Mark Butler and Principal Director John Bilmon with those of younger, Australian and overseas-trained, highly digitally-literate practitioners. Complementing this staff was the multi-disciplinary and cross-cultural collaboration with Arup (Australia) engineers and local Chinese architects, CSCEC-SDI. The dynamics of this team of local and international architects and engineers was crucial to the unique final design. The team split into four groups to workshop design principles, cultural values, and environmental and structural concepts for the project and quickly identified a range of possible seating bowl arrangements and developed design criteria for the envelope cover: the building should reflect the time and the place, be responsive to the immediate environment and its position as one of two gateway buildings; it should embody the concept of water in one of its forms; it should reflect ideas in traditional Chinese architecture and be culturally appropriate; and it should be a contemporary building - a cathedral for the Twenty-First Century - embodying the values and aspirations of China, testing materials, and expressing form in the most dynamic way.

Cutting-edge international practices frequently turn to nature for inspiration for design innovation. David Kirkland (Nicholas Grimshaw \& Partners) says "biomimicry is set to transform the way we live on Earth," while Mike Davies (Richard Rogers Partnership) says that "nature programmes ... are a huge resource of concepts and ideas contributing to the next building" (in Brookes and Poole $23 \& 53$ ). Many of the early proposals favoured by the PTW team were fluid, organic forms derived from nature, such as curvilinear roofs resembling petrified waves of water. But to some members of the cross-cultural team these curvilinear forms seemed inappropriate for a country whose temples, monuments and ancient cities are based on the geometry of the square. Members of the CSCEC-SDI cohort produced a conceptual model of 
wire mesh bent into a box acknowledging Chinese architectural traditions. Once the box form had been accepted, other team members seeking an innovative interpretation of tradition again turned to nature, particularly water and bubbles, for a solution to the treatment of the cube's façade. It was the close relationship between the architects and engineers within the multidisciplinary team, and the diversity of their educational backgrounds, that made possible a creative leap from Frei Otto's explorations of soap bubbles as film-like structures to an examination of the bubble connections in foam - the subject of nineteenth-century scientific research by Professor Weaire and Dr Phelan. Advanced computer software and iterative analysis techniques were employed to model the structural geometry of foam, which was then rotated and carved, producing a non-repetitive system: it breaks with modern conventions of standardisation by comprising 22,000 structural elements, 12,000 nodes and 4,000 different cladding panels.

In the Water Cube, innovative architecture is an outcome of a coalescence of Chinese cultural traditions, favouring axial arrangements and rectilinearity in the built environment, with current Western trends towards asymmetric organic forms and structures derived from nature. Kenzo Tange previously recognised the role of tradition fused with the modern in his own architecture for the Tokyo Games(1964). "The role of tradition is that of a catalyst, which furthers a chemical reaction but is no longer detectable in the end result" (Kultermann 9). This has been born out again in Beijing. For those attending the Olympic swimming events, the luminous, thermal, acoustic and kinetic environment of the Water Cube will stimulate the senses and enhance the perception of metaphorically inhabiting the nation of China.

\section{Conclusion}

The innovative design of the Water Cube combines fine-scale development in terms of the architectural application of ETFE and the geometrical possibilities of the space frame, with large leaps in conceptual thinking about architectural form and digital technology by a team of people working and thinking at the edge of their disciplines. The drivers for this innovation included the common desire by the consortium to optimise profit and market share for their respective companies, enhanced by the international profile afforded by the Olympic Games. It has been demonstrated that the drivers of innovation within the construction industry are historically strongest when there is a demand for radically new types of buildings and structures.

This paper has argued that the Olympic Games act as a driver for innovative architecture because host nations strive to couple challenging programmatic requirements with cultural aspirations. In the particular case of the Water Cube the propensity for innovation has been enhanced by the meeting of two cultures; Chinese traditions and Western technology. The box-like form represents a break in an era of ferment focused on structural forms derived from nature: the organic paradigm has been challenged by a multi-cultural project team designing a culturally-specific building for China. It has been achieved by the transfer of digital technology to architecture and engineering and by the application of an emergent building material, ETFE. The dynamics of the teamwork approach to design provided rich multi-cultural perspectives and diverse technological know-how that allowed for technology transfer and innovation to take place. The roles of teamwork and collaboration in creative endeavour and their interplay with special drivers such as mega-events, cultural imperatives, and unusual programmatic briefs, merit further investigation to identify and understand conditions likely to produce innovative architecture.

\section{References}

Abernathy, William J. The Productivity Dilemma: Roadblock to Innovation in the Automobile Industry. Baltimore: John Hopkins University Press, c1978.

Anderson, Philip \& Tushman, Michael L. "Technological Discontinuities and Dominant Designs: A Cyclical Model of Technological Change." Administrative Science Quarterly 35 (1990): 604-633.

Auerbach, Jeffrey A. The Great Exhibition of 1851: A Nation on Display. New Haven: Yale University Press, 1999.

Australian Bureau of Statistics. Innovation in Australian Business (8158.0) 2005.

Australian Bureau of Statistics. Notes on Innovation in Australian Business (8158.0) 2005. Accessed online 1.3.07 at http://www.abs.gov.au/AUSSTATS/abs@.nsf/ mf/8158.0?Open Document 
Bilmon, John. "Export: PTW." (Oral presentation) Import/Export Australian Architecture Abroad. Sydney: University of Technology, Sydney, 16 June 2007.

Bilmon, John \& Bosse, Chris. "National Aquatic Centre China." Architectural Review (Australia) 102 (2007): 92-98.

Bilmon, John. Interview with Kirsten Orr in the PTW Sydney office. 15 March 2007.

Bosse, Chris. Interview with Kirsten Orr in the PTW Sydney office. 27 March 2007.

Brookes, Alan J \& Poole, Dominique, eds. Innovation in Architecture. London: Spon Press, 2004.

Cooke, lan \& Mayes, Paul. Introduction to Innovation and Technology Transfer. Boston: Artech House, 1996.

Falck, Lindsay. Beijing National Swimming Centre. Unpublished case study, University of Pennsylvania, School of Design, December 2006.

Gann, David. Building Innovation: Complex constructs in a Changing World. London: Thomas Telford, 2000.

Herbig, Paul A. The Innovation Matrix: Culture and Structure Prerequisites to Innovation. Westport, Connecticut: Quorum Books, 1994.

Kultermann, Udo, ed. Kenzo Tange, 1946-1969: Architecture and Urban Design. London: Pall Mall Press, 1970.

Mahler, Victor. "Olympiastadion." Architectural Forum 137 (October 1972): 26-33.

Miller, Christine; Carr, Robert \& Cheung, Wilfred. "Construction Innovation - An Annotated Bibliography." Journal of Construction Innovation (October 2001). Accessed online 19.07.06 at http://www.cif.org/Presentations/AnnotatedBibliography/JCl_AnnoBiblio.htm

Orr, Kirsten. Olympic Architecture: Fulfilling the Great Dream. Unpublished Undergraduate Dissertation, School of Architecture, University of Technology, Sydney, 1994.

Orr, Kirsten. A Force for Federation: International Exhibitions and the Formation of Australian Ethos (1851-1901). PhD Thesis, University of New South Wales, 2006. Available at http://www.library.unsw.edu.au/ thesis/adt-NUN/public/adt-NUN20060518.124854/index.html

Rabagliati, Jonathan. Comparison Between Watercube, National Centre of Swimming, Beijing and 2002 Serpentine Pavilion. Emergent Technologies MA Dissertation, Architectural Association, London, 2006.

Roche, Maurice. Mega-Events and Modernity: Olympics and Expos in the Growth of Global Culture. London: Routledge, 2000.

Sundbo, Jon. The Theory of Innovation: Entrepreneurs, Technology and Strategy. Cheltenham: Edward Elgar, 1998.

Toy, Mary-Anne. "China Banking on More Than Gold." The Sydney Morning Herald 4-5 August 2007: 17.

Utterback, James M. Mastering the Dynamics of Innovation: How Companies can Seize Opportunities in the Face of Technological Change. Boston, Mass: Harvard Business School Press, 1994.

Von Stamm, Bettina. "Chapter 10: A Note on Teams." Managing Innovation, Design and Creativity. Chichester: John Wiley \& Sons, 2003: 125-138.

Wimmer, Martin. Olympic Buildings. Leipzig: George Prior Publishers, 1976.

Woyke, Elizabeth. "Material for an Architectural Revolution: ETFE." Business Week 24 April 2007. Accessed online 23.08.07 at http://www.businessweek.com/print/innovate/content/apr 2007/id20070424_903199.htm

Yao, Shujie. China to Become World's Largest Economy by 2038, Nottingham Professor Says. Accessed online 3.5.07 at www.nottingham.ac.uk/china-policy-institute/events/documents/ Shujie_YAo_Inaugural_Lecture_Press_Release.pdf. 